\title{
ANALISIS OPTIMALISASI PENGELOLAAN ASET PEMERINTAH KOTA PEKANBARU
}

\section{Optimization Analisis of Government Asset Management of Pekanbaru City}

\author{
Fahrial $^{1)}$, Sugito Hadi ${ }^{2)}$ \\ ${ }^{1)}$ Dosen Program Studi Agribisnis Fakultas Pertanian Universitas Islam Riau \\ ${ }^{2)}$ STIE Prakarti Mulya \\ Email :fahrial2018@agr.uir.ac.id
}

\begin{abstract}
This research aims to identify and inventory the assets, including form, size, physical, and legal, to know the market value (economic benefits) of the Pekanbaru city, to find out the value of the asset adjusted to its allocation or not, and to know the assets that are required to be optimized. The analysis of the drafting of optimization assets in Pekanbaru City is based on the performance, capacity, quality, and quantity of available assets. The research was carried out at the Pasar Sukaramai area, Jenderal Sudirman Street, Ahmad Yani street, Karet street, and Juanda street of Pekanbaru city. The research locations were selected purposively which are the potential area in Pekanbaru City. Analysis of land use optimization that is the Government's asset of Pekanbaru City used qualitative and quantitative approaches. A qualitative approach was used to analyze the characteristics of land assets and the surrounding area. The analysis method used in this study was a qualitative analysis that was done inductively. The analysis data was done using the highest and best use analysis (HBU) by analyzing the physical feasibility, regulatory eligibility, financial feasibility, and maximum productivity. The analysis results that are based on identification were obtained: a) there is a need for the firmness of the Pekanbaru City Government in terms of enforcing regulations relating to HPL or issuance of regulations related to HPL for making clear regulations, $b$. The present retribution has been not optimal yet, so the Regional Original Revenue (PAD) does not increase significantly, and c. Determination of the Land Value Zone (ZNT) consistently by following the market price is extremely required referring to the collaboration in determining the value of the percentage of land ownership.
\end{abstract}

Keywords: Optimization, Asset Management, Government

\begin{abstract}
Penelitian ini bertujuan untuk mengidentifikasi dan menginventarisasi aset, meliputi bentuk, ukuran, fisik, dan legal, dan mengetahui nilai pasar (manfaat ekonomis) terhadap Kota Pekanbaru, untuk mengetahui nilai aset telah disesuaikan dengan peruntukannya atau tidak dan mengetahui aset yang perlu dioptimalkan. Analisis penyusunan optimalisasi aset Kota Pekanbaru berdasarkan pada kinerja, kapasitas, kualitas dan kuantitas aset yang tersedia. Lokasi objek penelitian yaitu kawasan Pasar Sukaramai Jl. Jenderal Sudirman Kota Pekanbaru, kawasan Pasar Kodim Jl. Ahmad Yani Kota Pekanbaru dan kawasan Jl. Karet dan Jl. Juanda Kota Pekanbaru. Penentuan lokasi secara purposive sampling karena kawasan Potensi di Kota Pekanbaru. Penelitian optimalisasi pemanfaatan tanah aset Pemerintah Kota Pekanbaru ini menggunakan pendekatan kualitatif dan kuantitatif. Pendekatan kualitatif digunakan pada analisis karakteristik tanah aset dan analisis karakteristik wilayah sekitar. Metode analisis data yang digunakan dalam penelitian ini adalah analisis data kualitatif dilakukan secara induktif. Analisis data menggunakan analisis penggunaan tertinggi dan terbaik dengan menganalisis terhadap kelayakan fisik, kelayakan peraturan, kelayakan keuangan dan produktivitas yang maksimal. Hasil analisis berdasarkan idenditifikasi maka a) perlu adanya ketegasan Pemerintah Kota Pekanbaru dalam hal penegakan peraturan yang berkaitan dengan HPL atau penerbitan peraturan terkait HPL sehingga ada regulasi yang jelas, b. Retribusi yang dilakukan pada saat ini
\end{abstract}


belum optimal, Pendapatan Asli Daerah (PAD) yang tidak naik secara signifikan, c. Penentuan Zona Nilai Tanah (ZNT) secara konsisten dengan mengikuti harga pasar sangat dibutuhkan mengacu pada kerjasama menentukan nilai prosentase kepemilikan.

Kata kunci: Optimalisasi, Manajemen Aset, Pemerintah.

\section{PENDAHULUAN}

Pelaksanaan otonomi daerah memberikan kewenangan yang lebih luas kepada pemerintah daerah untuk mengatur daerahnya, sesuai dengan PP No.58 Tahun 2005 Pasal 1 Butir 5 Tentang Pengelolaan Keuangan daerah. Pengelolaan keuangan daerah tidak hanya mengoptimalkan pada potensi pajak dan retribusi saja, namun dapat dari pengelolaan aset daerah yang efektif dan efisien. Strategi optimalisasi pengelolaan aset daerah serta kontribusi aset daerah terhadap PAD guna melaksanakan tugas penyelenggaraan pemerintahan yang diharapkan dapat meningkatkan PAD.

Aset merupakan hal yang sangat fundamental bagi perseorangan maupun organisasi, karena merupakan bagian yang penting dalam pencapaian tujuan dari pemilik aset. Aset berarti kekayaan atau harta yang nantinya diharapkan mendatangkan benefit bagi pemiliknya. Aset daerah atau negara bisa juga berarti sumber daya alam, ekonomi dan sosial yang dimiliki oleh daerah atau negara tersebut. Aset daerah merupakan sumber daya penting bagi pemerintah daerah sebagai komponen utama dalam menyumbang Pendapatan Asli Daerah (PAD).

Dalam hal pengelolaan aset, pemerintah daerah harus menggunakan pertimbangan aspek perencanaan kebutuhan dan penganggaran, pengadaan, penerimaan, penyimpanan dan penyaluran, penggunaan, penatausahaan, pemanfaatan atau penggunaan, pengamanan dan pemeliharaan, penilaian, penghapusan, pemindahtanganan, pembinaan, pengawasan dan pengendalian, pembiayaan dan tuntutan ganti rugi agar aset daerah mampu memberika kontribusi optimal bagi pemerintah daerah yang bersangkutan.

Aset daerah merupakan sumberdaya penting bagi pemerintah daerah yakni sebagai penopang utama pendapatan asli daerah. Oleh karena itu, penting bagi pemerintah daerah untuk dapat mengelola aset secara memadai dan akurat.
Dalam Permendagri No. 19 Tahun 2016 disebutkan bahwa yang dimaksud dengan Pengelolaan barang daerah adalah suatu rangkaian kegiatan dan tindakan terhadap daerah yang meliputi:

1. perencanaan kebutuhan dan

2 penganggaran, pengadaan, penggunaan, pemanfaatan,

3. pengamanan

4. dan pemeliharaan,

5. penilaian,

6. pemindahtanganan,

7. pemusnahan,

8. penghapusan,

9. penatausahaan dan pembinaan, pengawasan dan

10. pengendalian.

Setelah sudah mengetahu arti dari pengelolaan aset itu apa, maka langkah selanjutnya yang perlu diketahui lagi adalah mengenai prinsip - prinsip dasar dalam pengelolaan tersebut. Hal ini dimaksudkan agar supaya memudahkan dalam hal pengelolaan aset daerah secara efisien dan efektif serta menciptakan transparansi kebijakan pengelolaan aset daerah. Tiga ( 3 ) prinsip dasar itu adalah sebagai berikut :

\section{Adanya perencanaan yang tepat.}

Pemerintah daerah sangat diharuskan untuk memiliki atau membuat perencanaan kebutuhan aset yang digunakan sebagai rujukan dalam pengadaan aset daerah. Berpijak dengan rencana yang sudah dibuat ini, kemudian pemerintah daerah baru bisa mengusulkan anggaran pengadaannya. Dan juga dalam hal Pengadaan barang atau kekayaan daerah harus dilakukan berdasarkan sistem tender (compulsory competitive tendering contract). Hal ini dilakukan dengan tujuan agar pemerintah daerah dan masyarakat tidak dirugikan. Untuk itu perlunya dibuat perencanaan strategik, baik yang sifatnya jangka pendek, menengah maupun jangka panjang mengenai pengelolaan aset daerah serta perlunya ditetapkan indikator kinerja 
pengelolaan kekayaan daerah. Indikator kinerja ini sangat penting untuk menilai kinerja pemerintah daerah dalam hal mengelola kekayaan daerah serta memberi petunjuk bagi pemerintah daerah untuk bertindak agar terhindar dari ekses negatif.

\section{Pelaksanaan/pemanfaatan secara efesien dan efektif}

Setelah menyusun dan memiliki perencanaan yang dilakukan secara tepat, tahapan selanjutnya adalah eksekusi atau tahap pelaksanaan. Dalam pelaksanaanya harus mengedepankan dan memperhatikan prinsip prinsip seperti efesiensi, efektivitas, transparansi dan akuntabilitas hal ini bertujuan supaya bisa optimal dalam mengelola aset daerah yang dimiliki dan sekali lagi Peran penting masyarakat dan DPRD juga sangat dibutuhkan dalam rangka melakukan pengawasan (monitoring) terhadap pemanfaatan aset daerah tersebut, agar tidak terjadi penyalahgunaan kekayaan milik daerah.pengelolaan juga menyangkut pendistribusian, pengamanan dan perawatan. Untuk itu diperlukan adanya unit pengelola kekayaan daerah yang profesional agar tidak terjadi overlapping tugas dan kewenangan dalam pengelolaan kekayaan daerah. Begitu pula dalam hal pengamanan terhadap kekayaan daerah, harus dilakukan secara memadai baik pengamanan fisik maupun melalui sistem pengendalian interen. Pengelolaan aset atau kekayaan daerah harus memenuhi prinsip akuntabilitas publik. ketiga (3) prinsipt tersebut adalah sebagai berikut :

1. Akuntabilitas kejujuran dan akuntabilitas hukum (accountabilty for probity and legality) ;

2. Akuntabilitas proses (process accountability);

3. Akuntabilitas kebijakan (policy accountability).

\section{Pengawasan (monitoring).}

Setelah ada penyusunan perencanaan yang tepat serta diikuti dengan tahapan pelaksanaan maka prinsip dasar ketiga atau yang terakhir adalah tahapan pengawasan. Pengawasan yang ketat perlu dilakukan sejak tahap perencanaan sampai pada tahap penghapusan aset. Dalam hal ini peran serta masyarakat dan DPRD serta auditor internal sangat penting. Keterlibatan auditor internal dalam proses pengawasan sangat penting untuk menilai konsistensi antara praktek yang dilakukan oleh pemerintah daerah dengan standar yang berlaku.

Selain itu pula, auditor internal juga sangat penting keterlibatannya untuk melakukan penilaian kebijakan akuntansi yang diterapkan, menyangkut pengakuan aset (recognition), pengukurannya (measurement) dan penilaiannya (evaluation).Agar bisa mengoptimalkan dalam pengelolaan kekayaan aset yang dimiliki suatu daerah, ada beberapa strategi yang perlu dilakukan atau diterapkan. Berikut strategi untuk optimalisasi pengelolaan kekayaan (aset) daerah :

1. Identifikasi dan inventarisasi nilai dan potensi aset daerah ;

2. Adanya sistem informasi manajemen aset daerah ;

3. Pengawasan dan pengendalian pemanfaatan aset dan ;

4. Pelibatan berbagai profesi atau keahlian yang terkait seperti auditor internal dan appraisal (penilai).

Tujuan dari pelaksanaan kegiatan Kajian Optimalisasi Pengelolaan Aset Pemerintah Kota Pekanbaru Tahun 2018 ini antara lain:

1. Mengidentifikasi dan menginventarisasi aset, meliputi bentuk, ukuran, fisik, legal, dan mengetahui nilai pasar (manfaat ekonomis) terhadap PAD Kota Pekanbaru.

2 Untuk mengetahui Nilai Aset telah disesuaikan dengan peruntukannya atau tidak.

3. Mengetahui aset yang perlu di optimalkan, sehingga diperoleh rekomendasi berupasasaran, strategi dan program untuk optimalisasi aset yang diteliti.

\section{METODOLOGI PENELITIAN}

Kajian optimalisasi pemanfaatan tanah aset Pemerintah Kota Pekanbaru ini menggunakan pendekatan penelitian kualitatif dan kuantitatif. Pendekatan kualitatif digunakan pada analisis karakteristik tanah aset dan analisis karakteristik wilayah sekitar, serta mendeskripsikan atau menjelaskan hasil dari analisis kuantitatif. 


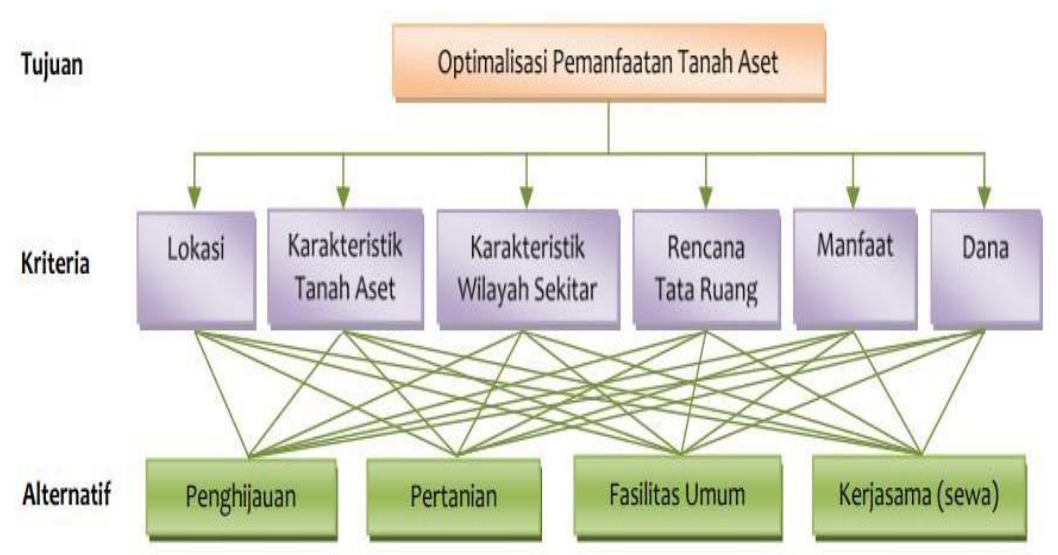

Gambar 1. Optimalisasi Pemanfaatan Tanah Aset

\section{Jenis Data}

berupa :

Penelitian ini menggunakan informasi

1. Rencana Kerja Anggaran (RKA) Dokumen Pelaksana Anggaran Tahun 2018.

2. Gambaran Umum dan potensi daerah Kota Pekanbaru

3. Data Kelayakan fisik berupa bentuk tanah dan ukuran, topografi tanah, lokasi tanah dan sarpras serta aksesibilitas.

4. Dokumen peraturan (legal formal) berupa UU, PP, Permen, Perda dan Perwako Pekanbaru yang masih berlaku

5. Data Retribusi dari BAPENDA Kota Pekanbaru Tahun 2013 sd 2017 mengenai Kontribusi Perolehan Retribusi Pemakain Kekayaan Daerah Terhadap PAD.

\section{Metode Pengumpulan Data}

Data yang digunakan oleh penulis diperoleh dengan metode :

1. Observasi, untuk memperoleh informasi mengenai bagaimana bagian keuangan mendapat laporan dari seluruh OPD dengan cepat.

2. Wawancara,dan

3. Dokumentasi

\section{Analisis Data}

Penelitian ini menggunakan Analisa Deskriptif kuantitatif, yaitu data yang diperoleh dianalisis sedemikian rupa sehingga diperoleh potensi dari optimalisasi pengelolaan Aset daerah Kota Pekanbaru.

Penelitian ini menggunakan Analisa Kuantitatif dimana penyusunan penelitian ini harus melalui beberapa tahapan, yaitu tahap pengumpulan data, tahap penyetaraan kegiatan, dan tahap pembentukan model.

Langkah ini mengacu dari tujuan penelitian yang akan dilaksanakan. Metode analisis data yang digunakan dalam penelitian ini adalah analisis datakualitatif dilakukan secara induktif, yaitu penelitian kualitatif tidak dimulai darideduksi teori tetapi dimulai dari fakta empiris. Penelitian dilakukan langsung ke objek penelitian, mempelajari, menganalisis dan menarik kesimpulan dari fenomena yang ada di lapangan. Analisis data dilakukan dilakukan dengan menggunakan analisis Penggunaan Tertinggi dan Terbaik (Highest and Best Usel $H B U$ ) denganmenganalisis terhadap kelayakan fisik, kelayakan peraturan, kelayakan keuangan danproduktivitas yang maksimal.

1) Mengidentifikasi dan menginventarisasi aset, meliputi bentuk, ukuran, fisik, legal, dan mengetahui nilai pasar (manfaat ekonomis) terhadap PAD Kota Pekanbaru. Langkah ini dilakukan dengan cara sebagai berikut;

i. Analisis Kelayakan Fisik.

ii. Analisis Legal yang meliputi untuk gedung.

iii. Analisis Keuangan yang meliputi;

a) Payback Period (PP)

b) Average Rate of Return (ARR).

c) Net Present Value (NPV).

d) Internal Rate of Retun (IRR).

2) Analisis Data Kajian

Analisis yang digunakan dalam kajian ini menggunakan angka Tahun 2018 hingga 2023. Adapun analisis yang digunakan adalah; 
a) Analisis Trend Kemampuan Perolehan Retribusi Pemakaian Kekayaan Daerah (RPKD).

b) Analisis Trend Kontribusi Perolehan Retribusi Pemakaian Kekayaan Daerah (RPKD) terhadap Retribusi Jasa Usaha.

c) Analisis Trend Kontribusi Perolehan Retribusi Pemakaian Kekayaan Daerah (RPKD) terhadap Pendapatan Asli Daerah (PAD)

d) Analisis Uji Pengaruh Pemanfaatan BMD terhadap PAD. Untuk menguji pengaruh pemanfaatan BMD terhadap PAD digunakan model regresi sederhana yakni;

$\mathrm{PAD}=\mathrm{a}+\beta \mathrm{PBMD}+\xi$

Dimana;

PAD = Pendapatan Asli Daerah PBMD = Pemanfaatan Barang Milik Daerah

$\beta$ (beta) $=$ Koefisien Pengaruh

PBMD terhadap PAD

$\xi=$ Epsilon atau Standard Error

3) Mengetahui aset yang perlu dioptimalkan, sehingga diperoleh rekomendasi berupasasaran, strategi dan program untuk optimalisasi aset yang diteliti. Untuk mengetahui asset yang perlu dioptimalkan maka perlu diketahui bahwa bentuk manajemen aset daerah meliputi antara lain sebagai berikut;

a. BOT (Build-Operate-Transfer) yaitu manajemen tanah dan atau bangunan milik/dikuasai Pemerintah Daerah oleh pihak ketiga dengan cara pihak ketiga membangun bangunan siap pakai dan atau menyediakan, menambah sarana lain berikut fasilitas di atas tanah dan atau bangunan tersebut dan mendayagunakannya selama dalam waktu tertentu untuk kemudian setelah jangka waktu berakhir menyerahkan kembali tanah dan bangunan dan atau sarana lain berikut fasilitasnya tersebut beserta pendayagunaannya kepada daerah, serta membayar kontribusi sejumlah uang atas manajemennya yang besarnya ditetapkan sesuai dengan kesepakatan.

b.BTO (Build-Transfer-Operate) yaitu manajemen tanah dan atau bangunan milik/dikuasai Pemerintah Daerah oleh pihak ketiga dengan cara pihak ketiga membangun bangunan siap pakai dan atau menyediakan, menambah sarana lain berikut fasilitas yang melekat pada tanah dan atau bangunan tersebut dan setelah selesai pembangunannya diserahkan kepada daerah untuk kemudian oleh Pemerintah Daerah tanah dan bangunan siap pakai dan atau sarana lain berikut fasilitasnya tersebut diserahkan kembali kepada pihak ketiga untuk didayagunakan selama jangka waktu tertentu, dan atas manajemennya tersebut pihak ketiga dikenakan kontribusi sejumlah uang yang besarnya sesuai dengan kesepakatan.

c. BOO (Build-Operate-Transfr) yaitu perikatan antara Pemerintah Daerah dengan Pihak Ketiga dengan ketentuan tanah milik Pemerintah Daerah, Pihak Ketiga membangun dan membiayai sampai selesai, setelah pembangunan selesai Pihak Ketiga mengoperasikannya dan pada akhir tahun konsensi pihak ketiga menyerahkan kepada Pemerintah Daerah.

4) Untuk rekomendasi berupa sasaran, strategi dan program maka digunakan analisis kuantitatif. Adapun pendekatan kuantitatif lebih berkenaan dengan kegiatan analisis data bersifat statistik (nilai/skor/angka/numerik) menggunakan pembobotan, berupa metode pairwise comparison atau AHP (Analytical Hierarchy Process), yaitu suatu model pengambilan keputusan yang berguna untuk menentukan prioritas dan membuat keputusan terbaik, dengan bantuan $M s$ Excel dan Expert Choice. Diagram hierarki dalam analisis AHP yang terdiri dari tujuan penelitian, kriteria-kriteria yang perlu dipertimbangkan dalam kegiatan pemanfaatan tanah aset dan alternatif pemanfaatan tanah asset.

\section{HASIL DAN PEMBAHASAN}

Pemaparan intisari dari hasil studi kasus analisis Highest and Best Use (HBU) aset HPL Kota Pekanbaru adalah untuk menjawab rumusan masalah, solusi pengembangan manakah yang paling tepat berdasarkan hasil 
studi kasus analisis highest and best use (HBU) HPL Pemko Pekanbaru yang meliputi aspek legal, aspek fisik, aspek finansial dan aspek produktivitas maksimal. Aset HPL Kota Pekanbaru yang dilakukan dalam penelitian ini terletak di Jalan Jendral Sudirman, Jalan. KH Wahid Hasyim, Jalan Agus Salim, Jalan Cengkeh, Jalan Imam Bonjol, Jalan Kopi, Jalan Hos Cokroaminoto, Jalan Gatot Subroto, Jalan KH. Hasyim Asyari, Jalan Wolter Monginsidi, Jalan Gambir, Kopi, Jalan Nilam, Jalan Karet dan Jalan Juanda di Kota Pekanbaru, Provinsi Riau. Jika dilihat pada Draft RTRW maka termasuk ke dalam Zona Wilayah Pembangunan I (satu) yang meliputi wilayah perdagangan, jasa, perkantoran dan pemukiman.

Hasil di lapangan menunjukkan kondisi Jalan Sudirman di dekata Kawasan HPL cukup semrawut, parkir yang memakai badan jalan sehingga menyulitkan untuk berjalan baik bagi pejalan kaki maupun kendaraan. Sehingga diperlukan juga tempat parkir dan pedestrian yang repsentatif. Alternative pengembangan adalah pada perdagangan (ruko), pasar, parkir dan pedestrian. Hasil wawancara dengan menggunakan sampel acak diketahui, rata- rata pedagang lama mengharapkan keberadaan ruko tetap dilanjutkan, hanya saja diakibatkan belum selesainya perbaikan Ramayana sehingga menyulitkan parkir dan orang berjalan, maka omset penjualan di sekitar Jalan Wolter Monginsidi dan Jalan KH. Hasyim Asyari menjadi sepi.

\section{A. Aspek Kelayakan Fisik}

Berdasarkan data dan analisis terhadap aspek fisik, bahwa lahan HPL Pemko Pekanbaru mempunyai luas $\pm 55.405 \mathrm{~m} 2$ dan letaknya terpisah. Ukuran tersebut memungkinkan untuk ruko dan parkir serta pedestrian di atasnya. Bentuk tanahnya persegi empat, sehingga cocok dilakukan pengembangan apapun di atasnya. Hasil dari digitasi melalui google earth pro yang dilakukan analisis topografi tanah berdasarkan kawasan yang berada di kawasan Pasar Sukaramai Jalan Jendral Sudirman, kawasan pasar Kodim Jalan Ahmad Yani serta Jalan Karet dan Jalan Juanda, tingkat ketinggian minimal diatas 13 meter hingga 23 meter dan ini menandakan bahwa topografi tanah pada daerah yang diteliti cukup datar dan strategis untuk pembangunan ruko, dan hal ini tergolong dataran yang bagus.

Lokasi lahan juga sangat strategis yaitu berada di tengah-tengah Kota Pekanbaru dan termasuk ke dalam kawasan strategis ekonomi. Kondisi ini pun didukung oleh aksesbilitas yang baik. Data-data yang menunjukan kriteria aspek fisik HPL Pemko Pekanbaru sebagai objek kajian HBU dapat dilihat pada tabel 5.1. Kesimpulan yang dapat diambil berdasarkan data dan analisis dinyatakan bahwa pengembangan hotel ruko dan parkir / pedestrian layak secara fisik. Adapun penjelasan tabel dan peta mengenai aksesbilitas dapat dilihat pada lampiran 1. Setelah didapat kelayakan secara fisik dan legal, maka selanjutnya dapat dilakukan analisis terhadap aspek legalnya.

\section{B. Aspek Legal Aset}

Berdasarkan Draft RTRW Kota Pekanbaru dalam penggunaan suatu lahan perlu diperhatikan persyaratan-persyaratan agar dalam penggunaan suatu lahan tidak menyalahi aturan yang berlaku. Persyaratan-persyaratan yang perlu diperhatikan antara lain persyaratan administratif seperti perizinan dan persyaratan teknis yang meliputi Garis Sempadan Bangunan (GSB) terhadap pagar depan, samping, dan belakang; Koefisien Dasar Bangunan (KDB); Koefisien Lantai Bangunan (KLB), Koefisien Dasar Hijau (KDH) dan peruntukan lahan sesuai dengan yang telah ditetapkan oleh Pemerintah Kota Pekanbaru. Dalam hal ini peneliti memberikan beberapa alternatif untuk optimalisasi aset di HPL Pemko Pekanbaru. Adapun pilihan tersebut; 1) semua ruko yang ada diperbaiki karena mengingat umur ekonomi dan kondisi yang sudah lama; 2) pada Blok BDE ruko diperbaiki dan disiapkan lahan parkir pada Blok A, hal ini disebabkan karena kemacetan maka pembeli enggan untuk masuk ke Blok tersebut karena sulitnya parkir; 3) pada Blok ABDE dibangun "Pekanbaru Superblok" berupa kantor dan pusat perbelanjaan yang memiliki basement sebagai salah satu ikon di Kota Madani.

\section{Alternatif}

\section{Alternatif Pertama}

Pada alternatif pertama ini, semua Ruko yang ada diperbaiki, untuk asumsi perincian 
penghitungan untuk Blok A HPL Pemko Pekanbaru adalah sebagai berikut; BLOK A

- DB (Koefisien Dasar Bangunan $)=90 \%$

- DH (Koefisien Daerah Hijau) $=10 \%$

- LB (Koefisien Luas Bangunan)= 5,6

$\mathrm{KDH}=10 \% \times \mathrm{LDP}$

$$
\begin{aligned}
& =10 \% \times 2.957 \mathrm{~m}^{2} \\
& =295,7 \mathrm{~m}^{2}
\end{aligned}
$$

Jadi dari luas total LDP seluas $2.957 \mathrm{~m}^{2}$ harus disisakan lahan seluas $295,7 \mathrm{~m}^{2}$ dan harus digunakan untuk ruang terbuka hijau.

\section{Rekapitulasi Hasil Analisis}

Dalam rangka optimalisasi aset lahan HPL Kota Pekanbaru, maka dilakukan analisis kelayakan investasi yang meliputi kajian HBU selanjutnya dilakukan kajian pemilihan alternatif kerjasama usahanya. Penjelasan mengenai kajian HBU lahan HPL Pemko Pekanbaru dilakukan untuk menjawab rumusan masalah pertama dalam penelitian ini. Analisis kelayakan bisnis dilakukan untuk menjawab rumusan masalah kedua dalam penelitian ini. Sedangkan untuk menjawab rumusan masalah ketiga dilakukan kajian pemilihan alternatif kerjasama usaha yang paling ekonomis dengan mengggunakan analisis terhadap cashflow. Berdasarkan hasil kajian HBU nya yang meliputi analisis terhadap aspek legal aset, aspek fisik aset, aspek finansial dan aspek produktivitas maksimal, diketahui bahwa penggunaan tertinggi dan terbaik bagi aset lahan HPL Pemko Pekanbaru adalah pengembangan berupa hotel. Hasil kajian HBU ini menjadi sebuah ide bisnis yang kemudian perlu diuji kelayakan bisnisnya.

Kerjasama usaha yang paling ekonomis bagi perusahaan dengan kriteria highest revenue dan reduction cost adalah alternatif kerjasama usaha yang akan dipilih. Untuk itu dilakukan pemilihan bentuk kerjasama usaha yang terdiri dari kerjasama Bangun Guna Serah (Build Operate and Transfer/BOT), Bangun Guna Serah (Build, Transfer dan Operate) dan Bangun Guna Milik (Build Operate and Owned/BOO). Hasil analisis menunjukan bahwa penggunaan tertinggi dan terbaik aset lahan HPL Pemko Kota Pekanbaru adalah pengembangan berupa hotel.

\section{Alternatif Kedua}

Pada alternatif kedua, Blok BDE ruko diperbaiki dan disiapkan lahan parkir pada Blok A. Adapun penghitungan investasi dan analisis finansial tetap sama. Adapun luas lahan BDE adalah sebesar $11.422 \mathrm{~m}^{2}$. Sedangkan lahan parkir yang digunakan adalah pada Blok A dengan luas $2.957 \mathrm{~m}^{2}$. Diasumsikan bahwa untuk lahan BDE disiapkan kios sebanyak 113 atau sebanyak jumlah total kios di Blok A,B,D dan E. Jika tersedia akses parkir, maka pengunjung akan menjadi ramai sehingga biaya sewa akan naik. Jika dilihat pada saat ini harga pasar sewa ruko pada saat ini adalah Rp. 100.000.000,-l tahun. Jika sudah dirombak bukan tidak mungkin harganya akan lebih naik lagi. Adapun dalam hal ini peneliti meletakkan harga pasar sewa ruko adalah Rp. 100.000.000 / tahun, mengingat akses parkir dan lokasi yang menjadi strategis.

\section{Alternatif Ketiga}

Berbeda dengan alternatif pertama dan kedua, yang hanya masing mengandalkan membangun ruko, pada alternatif ketiga peneliti menawarkan pilihan berupa bangunan superblok. Dimana yang menjadi konsentrasi adalah pada lahan Blok A,B,D dan E, hal ini disebabkan lahan tersebutlah yang paling potensi dan bentuknya bisa menyatukan atau menghasilkan lahan yang cukup luas dibandingkan dengan Blok lain. Dengan luas total sebesar $14.379 \mathrm{~m}^{2}$, dengan rincian luas lahan rinciannya yaitu luas lahan Blok A sebesar $2.957 \mathrm{~m}^{2}$, luas lahan Blok B sebesar $3.633 \mathrm{~m}^{2}$, luas lahan Blok D sebesar $4.721 \mathrm{~m}^{2}$ dan luas lahan Blok E sebesar $3.068 \mathrm{~m}^{2}$. menggunakan rumusan pada Tabel 5.12. Dengan melihat jumlah lantai pada The Peak Apartemen yang tingginya 29 lantai. Maka peneliti mencoba mesimulasi pada lahan Blok $\mathrm{A}, \mathrm{B}, \mathrm{D}$ dan $\mathrm{E}$ dengan tinggi maksimal 25 lantai.. Dalam hal ini, luas lahan Blok ABDE dibagi menjadi 3 bagian yaitu 1) 5 lantai; 2)15 lantai dan 3) 25 lantai. Untuk memudahkan dan mengurai kemacetan maka peneliti meggunakan basemen sebagai lahan parkir. Adapun lantai dasar yang digunakan adalah sebesar $12.941,10 \mathrm{~m}^{2}$. Dari hasil penghitungan 
diketahui jumlah LDP adalah sebesar 14.379 $\mathrm{m}^{2}$ dan ini dijadikan untuk basemen. Sedangkan jumlah Lantai Dasar untuk dibangun adalah sebesar 12.941,10 $\mathrm{m}^{2}$. Dengan asumsi 3 (jenis) lantai yang berbeda ketinggiannya yakni 5 (lima), 15 (lima belas) dan 25 (duapuluh) lantai, dengan jumlah yang sama berarti luas lahan $12.941,10 \mathrm{~m}^{2}$ dibagi 3 (tiga) sehingga menjadi $4.313,70 \mathrm{~m}^{2}$, setiap jenjang lantai.

Untuk penghitungan basemen (lahan parkir) dengan luas sebesar $14.739 \mathrm{~m} 2$, diperoleh biaya pembangunannya sebesar US \$ $5.061 .183,33$ dikalikan dengan $150 \%$ sebagai koefisien basemen sehingga diperoleh angka menjadi US \$ 7.591.775,-. Lalu jumlah tersebut dikalikan dengan kurs dollar sebesar Rp. $15.000,-/$ US \$ 1 yang berarti memperoleh angka sebesar Rp. 113.876.624.883,-.

\section{Aspek Finansial}

Analisis aspek finansial hotel bertujuan untuk mengetahui apa saja yang perlu diperhatikan dalam merencakan bangunan yang sesuai dengan peraturan- peraturan yang telah ditetapkan dan sekaligus dapat mengetahui estimasi biaya dalam perencanaan bangunan tersebut. Dalam analisis aspek finansial, faktorfaktor kelayakan keuangan yang meliputi, Payback Periode (PP), Average Rate of Return (ARR) dijadikan parameter kelayakannya dan Analisa produktivitas maksimum. Akan tetapi sebelum dilakukan dahulu perencanaan biaya investasi yang diperlukan dalam perencanaan bangunan ini, dengan memperhitungan pendekatan biaya yang dilakukan secara makro.

Analisis aspek finansial hotel bertujuan untuk mengetahui apa saja yang perlu diperhatikan dalam merencakan bangunan yang sesuai dengan peraturan-peraturan yang telah ditetapkan dan sekaligus dapat mengetahui estimasi biaya dalam perencanaan bangunan tersebut. Dalam analisis aspek finansial, faktorfaktor kelayakan keuangan yang meliputi Payback Periode (PP), Average Rate of Return (IRR) dan analisis Produktivitas Maksimum dijadikan parameter kelayakannya. Dengan keputusan finansial dinyatakan layak apabila;

a. PP lebih cepat lebih baik

b. ARR > tingkat bunga berlaku c. Produktivitas maksimum > Nilai pada saat ini.

\section{Payback Period (PP)}

Untuk menilai apakah aset layak diterima atau tidak dari segi PP, maka hasil perhitungan PP harus lebih kecil dari umur investasi. Diketahui pada Blok A nilai investasi adalah Rp. 46.836.800.859,38. Untuk prediksi EAT (Earning After Tax) diprediksi berdasarkan angka pendapatan dari yakni sebesar 26 ruko dikalikan dengan prediksi biaya sewa yakni Rp.75.000.000,- yang berarti total pendapatan Rp. 1.950.000.000,-. Jika diketahui tingkat bunga per 25 Oktober 2018 adalah sebesar $5,75 \%$ maka diperoleh penghitungan PP sebagai berikut; Dengan menggunakan rumus $\mathrm{PP}=$ (investasi awal : arus kas) Dengan menggunakan rumus $\mathrm{PP}=$ (investasi awal : arus kas) $\mathrm{PP}=24,02$. Yang berarti Payback Period adalah selama 21 tahun, 2 bulan. Dan dapat disimpulkan untuk PP adalah layak.

\section{Average Rate of Return (ARR)}

ARR merupakan cara mengukur rata-rata pengembalian bunga dengan cara membandingkan antara rata-rata laba setelah pajak dengan rata-rata investasi. Akan tetapi dalam hal ini disebabkan Pemko Pekanbaru memperoleh investasi tersebut, maka EAT = EBIT (Earning Before Income Tax). Rumusnya adalah;

$\mathrm{ARR}=($ Pendapatan Bersih / Investasi $) \times 100 \%$

$\mathrm{ARR}=(1.950 .000 .000 / 46.836 .800 .859,38) \mathrm{x}$

$100 \%$

$\mathrm{ARR}=0,0416 \times 100 \%$

$\mathrm{ARR}=4,16 \%$

Yang berarti 4,6\% < Bunga yakni 4,6\% $<5,75$ $\%$ yang berarti usulan pembangunan diterima. Meskipun demikian, hal ini merupakan yang wajar, adapun penyebabnya adalah Pemko Pekanbaru bermodalkan tanah saja, tidak melibatkan dana yang ada.

\section{Perencanaan Biaya Investasi}

Perencanaan biaya investasi dalam analisis HBU harus dilakukan agar mengetahui gambar berapa besaran biaya yang dibutuhkan terhadap analisis besaran lahan HPL Pemko Pekanbaru. Biaya-biaya yang dipertimbangkan didapat dari beberapa pendekatan, antara lain;

a. Biaya bangunan

b. Biaya peralatan tetap. 
c. Biaya tanah

d. Jasa profesi

e. Biaya peralatan bergerak

f. Biaya administrasi

g. Biaya lain-lain

Analisis aspek finansial hotel bertujuan untuk mengetahui apa saja yang perlu diperhatikan dalam merencakan bangunan yang sesuai dengan peraturan-peraturan yang telah ditetapkan dan sekaligus dapat mengetahui estimasi biaya dalam perencanaan bangunan tersebut. Dalam analisis aspek finansial, faktorfaktor kelayakan keuangan yang meliputi Payback Periode (PP), Average Rate of Return (IRR) dan analisis Produktivitas Maksimum dijadikan parameter kelayakannya. Dengan keputusan finansial dinyatakan layak apabila

\section{KESIMPULAN}

1. Lahan HPL Pemko Pekanbaru mempunyai luas $\pm 55.405 \mathrm{~m} 2$ dan letaknya terpisah. Secara aspek fisik bentuk tanah Kota Pekanbaru adalah segi empat dengan kuntur tanah relative datar dean aspek legal secara umum baik dan KDH sudah termasuk di dalamnya yakni minimal $10 \%$, begitu juga dengan GSB-nya sudah memenuhi syarat secara keseluruhan.

2. Analisis ini terdiri dari 3 (tiga) alternatif yakni 1) semua ruko yang ada diperbaiki karena mengingat umur ekonomi dan kondisi yang sudah lama; 2) pada Blok BDE ruko diperbaiki dan disiapkan lahan parkir pada Blok A, hal ini disebabkan karena kemacetan maka pembeli enggan untuk masuk ke Blok tersebut karena sulitnya parkir; 3) pada Blok ABDE dibangun "Pekanbaru Superblok" berupa kantor dan pusat perbelanjaan yang memiliki basement sebagai salah satu ikon di Kota Madani.

3. Pada kajian AHBU di alternatif pertama, hanya Blok A, K4 dan L saja yang layak untuk dilakukan perubahan secara mendasar, sedangkan pada blok lainnya disarankaan untuk diperbaiki atau dirombak secara minor. Pada analisis AHBU di alternatif kedua, Blok ABDE layak untuk dibangun ruko dan parkir. Selain itu juga peneliti memandang penting karena parkir disini untuk memudahkan konsumen sehingga keluhan konsumen jalan padat dan keluhan pedagang akses jalan sulit dilalui sehingga membuat pelanggan sepi dapat teruraikan.
Pada analisis AHBU di alternatif ketiga, pada Blok ABDE untuk pembangunan superblock sangat layak dilakukan, tidak hanya sampai disitu Jalan Jendral Sudirman sebagai sentra Kota Pekanbaru dapat memiliki ikon yang dapat dibanggakan

\section{SARAN}

a. Perlu adanya ketegasan Pemko dalam hal penegakan peraturan yang berkaitan dengan HPL atau penerbitan peraturan terkait HPL sehingga ada regulasi yang jelas.

b. Retribusi yang dilakukan pada saat ini belum optimal, hal ini terlihat bahwa PAD yang tidak naik secara signifikan.

c. Penentuan Zona Nilai Tanah (ZNT) secara konsisten dengan mengikuti harga pasar sangat dibutuhkan mengingat dalam kerjasama menentukan nilai prosentase kepemilikan.

\section{DAFTAR PUSTAKA}

Abdullah, Thamrin, dan Tantri 2012, Manajemen PemasaranBadan Pusat Statistik.2016. Riau Dalam Angka.Badan Pusat Statistik Provinsi Riau, Pekanbaru.

A. Gima Sugiama. (2010). Metode Riset Bisnis dan Manajemen. Edisi Pertama, Bandung: Guardaya Intimarta.

Arikunto, Suharsimi 2010, Prosedur Penelitian Suatu Pengantar Praktek. Rineka Cipta. Jakarta.

Britton, W., Connellan. O.P., and Crofts, M. 1989. The Economic, Efficient and Effective Management of Public Landed Assets. Surrey County Council and Kingston University.

George R. Terry (dalam Sugiama, 2010) "Management is a distinct process consisting of planning, organizing, actuating and controlling, utilizing in each both science and art, and followed in order to accomplish predetermined objective",

Hastings, Nicholas A. J. 2010. Physical Asset Management. Springer.London

Permendagri No. 19 Tahun 2016

Peraturan Pemerintah Nomor 25 Tahun 2000 Tentang Kewenangan Pemerintah dan Kewenangan Provinsi sebagai Daerah Otonom (Lembaran Negara Republik 
Indonesia Tahun 2000 Nomor 54, Tambahan Lembaran Negara Republik Indonesia Nomor 3952);

Peraturan Pemerintah Nomor 58 Tahun 2005 tentang Pengelolaan Keuangan Daerah (Lembaran Negara Republik Indonesia Tahun 2005 Nomor 140, Tambahan Lembaran Negara Republik Indonesia Nomor 4578);

Peraturan Pemerintah Nomor 8 Tahun 2006 tentang Laporan Keuangan dan Kinerja Instansi Pemerintah (Lembaran Negara Republik Indonesia Tahun 2006 Nomor 25, Tambahan Lembaran Negara Republik Indonesia Nomor 4614).

Peraturan Pemerintah Nomor 27 Tahun 2014 tentang Pengelolaan Barang Milik Negara/Daerah .

Peraturan Presiden Republik Indonesia Nomor 75 Tahun 2017 Tentang Penilaian Kembali Barang Milik Negara/Daerah.

Peraturan Menteri Dalam Negeri Nomor 21 Tahun 2011 tentang Perubahan Kedua atas Peraturan Menteri Dalam Negeri Nomor 13 Tahun 2006 tentang Pedoman Pengelolaan Keuangan Daerah Menteri Dalam Negeri Nomor 13 Tahun 2006 tentang Pedoman Pengelolaan Keuangan Daerah.

Peraturah Menteri Dalam Negri Nomor 19 Tahun 2016 tentang pedoman Pengelolaan Barang Milik Daerah.

Peraturan Menteri Dalam Negeri Nomor 1 Tahun 2014 tentang Produk Hukum Daerah (Berita Negara Tahun 2014 Nomor 32);

Peraturan Menteri Dalam Negeri Nomor 7 Tahun 2006 Tentang Standarisasi Serana dan Prasarana Kerja Pemerintah Daerah.

Perda Nomor 1 tahun 2011 Tentang RPJPD Tahun 2005-2025

Perda Nomor 9 Tahun 2016 Tentang Pembentukan Susunan Perangkat Daerah Kota Pekanbaru.
PERWAKO No. 39 Tahun 2016 Tentang RKPD Kota Pekanbaru Tahun 2017.

Siregar, D. D. (2004). Manajemen Aset. Strategi Penataan Konsep Pembangunan Berkelanjutan Secara Nasional dalam Konteks Kepala Daerah Sebagai CEO's pada Era Globalisasi dan Otonomi Daerah. PT. Gramedia Pustaka Utama

Sugiyono, 2008. Metode Penelitian Adminstrasi. Alfabeta. Bandung.

Undang-Undang Nomor 61 Tahun 1958 tentang Pembentukan Daerah Swantantra Tingkat I Sumatera Barat, Jambi dan Riau (Lembaran Negara Republik Indonesia Tahun 1958 Nomor 112, Tambahan Lembaran Negara RI Nomor 1646;

Undang-Undang Nomor 17 Tahun 2003 tentang Keuangan Negara (Lembaran Negara Republik Indonesia Tahun 2003 Nomor 47, Tambahan Lembaran Negara Republik Indonesia Nomor 4286);

Undang-Undang Nomor 1 Tahun 2004 tentang Perbendaharaan Negara (Lembaran Negara Republik Indonesia Tahun 2004 Nomor 5, Tambahan Lembaran Negara Republik Indonesia Nomor 4355)

Undang-Undang Nomor 15 Tahun 2004 tentang Pemeriksaan Pengelolaan dan Tanggungjawab Keuangan Negara (Lembaran Negara Republik Indonesia Tahun 2004 Nomor 66, Tambahan Lembaran Negara Republik Indonesia Nomor 4400)

Undang-Undang Nomor 23 Tahun 2014 tentang Pemerintahan Daerah.

Undang-Undang Nomor 33 Tahun 2004 tentang Perimbangan Keuangan Antara Pemerintah Pusat dan Pemerintah Daerah (Lembaran Negara Republik Indonesia Tahun 2004 Nomor 126, Tambahan Lembaran Negara Republik Indonesia Nomor 4438) 